\title{
Forklift Operator Dies When Crushed between Forklift Overhead Guard and Mast
}
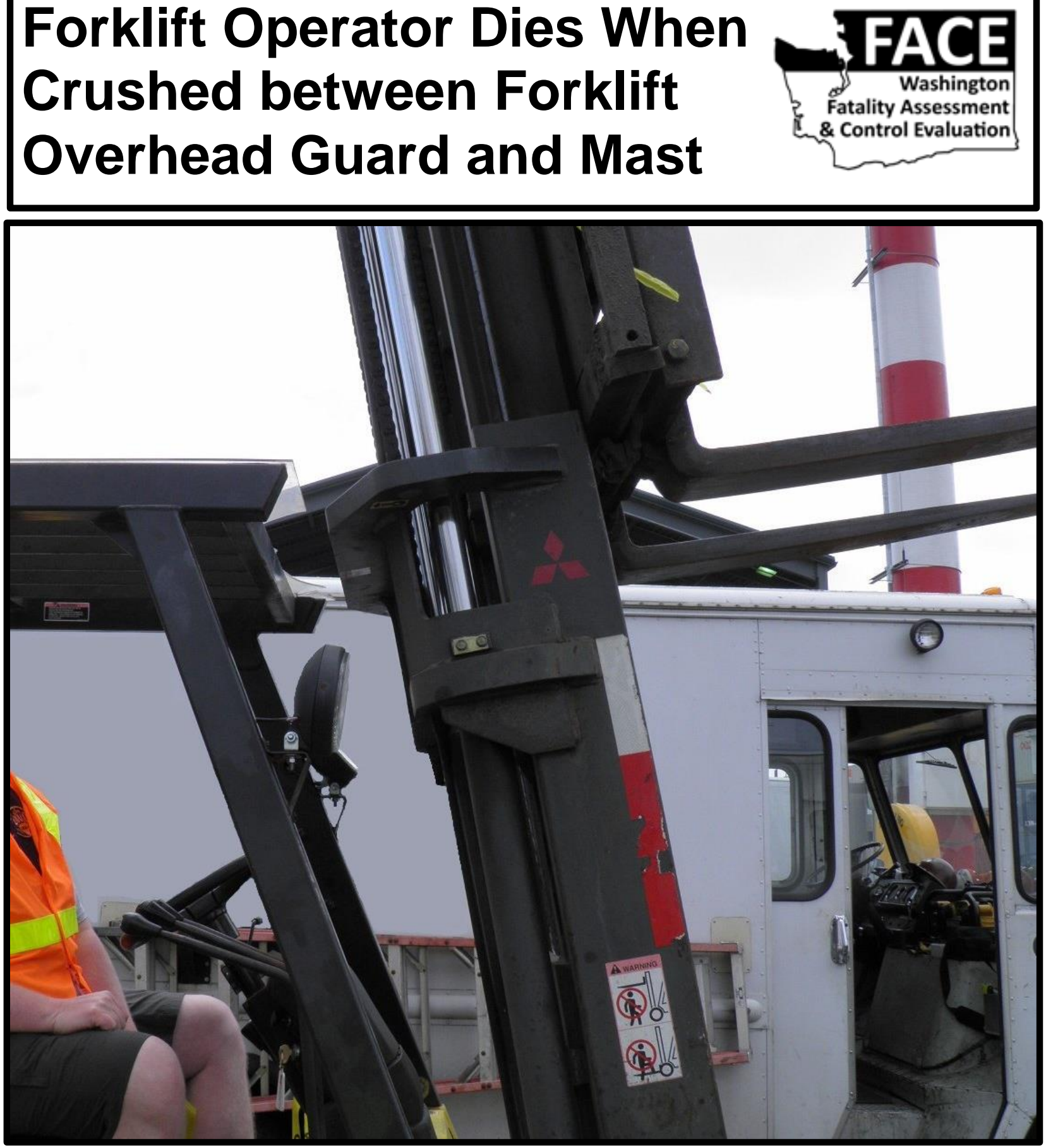

Investigation: \# 12WA015

Release Date: January 22, 2018

SHARP Report: \# 52-42-2018 


\section{Table of Contents}

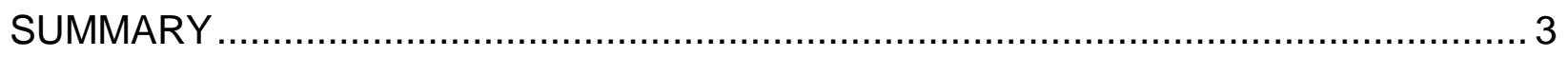

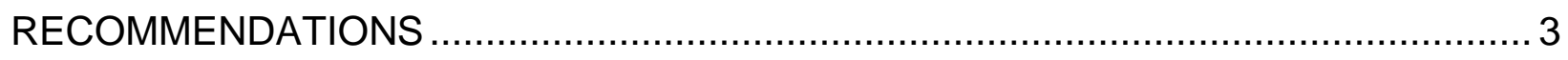

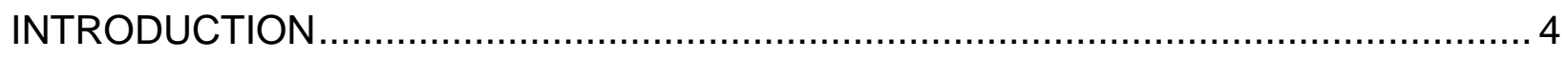

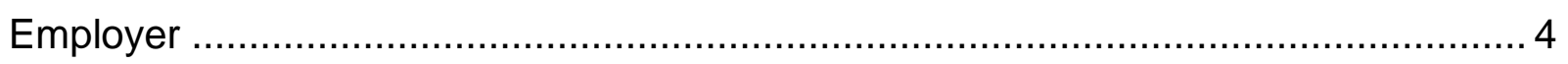

Employer Safety Program and Training ....................................................... 4

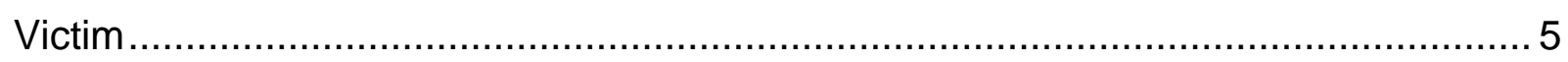

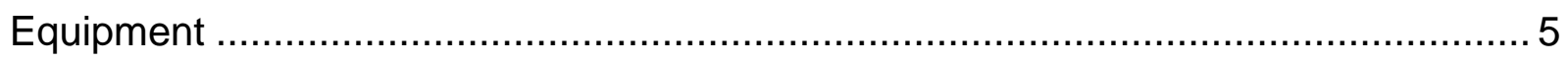

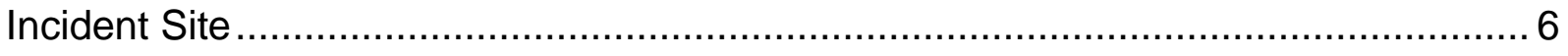

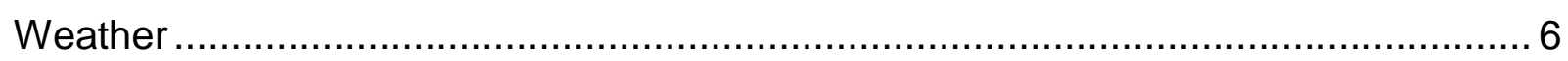

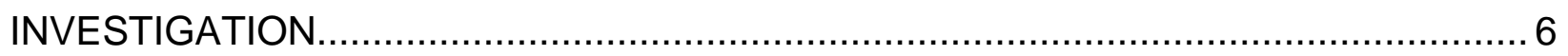

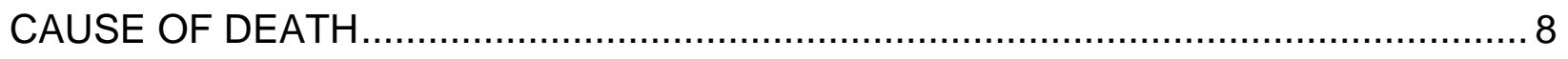

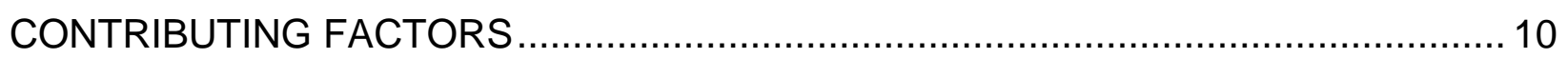

POST-INCIDENT CORRECTIVE ACTIONS TAKEN BY EMPLOYER.......................... 10

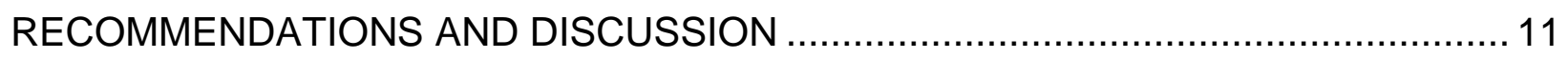

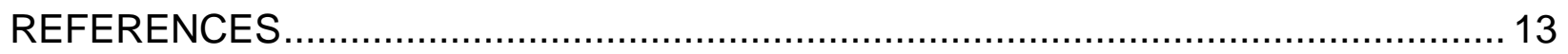

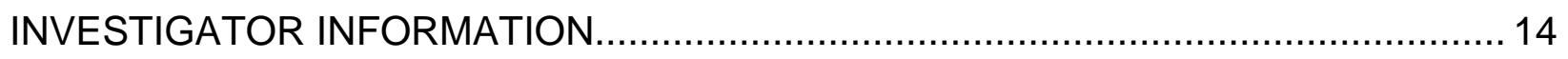

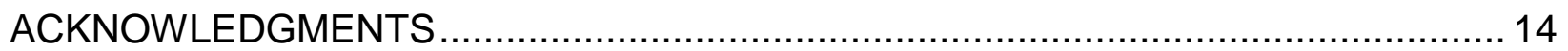




\section{SUMMARY}

In May of 2012, a 61-year-old longshore worker operating a forklift died when he was crushed between a forklift's mast and the operator's cab overhead guard. The incident occurred when he left the forklift operator's seat and climbed over the operator's console and stood on the dash between the mast and the overhead guard so that he could presumably look into a bin elevated on the forklift's forks. He did not turn off the forklift engine. As he was standing on the dash, his right foot moved backward and contacted the mast tilt control lever on the console. This caused the mast to tilt back, crushing his torso between the mast cross member and the overhead guard. Workers arrived and helped him down from the forklift and administered first aid. Fire department paramedics arrived in less than seven minutes. He was taken to a hospital where he died in the emergency room.

\section{RECOMMENDATIONS}

To prevent similar occurrences in the future, Washington State Fatality Assessment and Control Evaluation (FACE) investigators concluded that to protect employees from the hazard of being crushed between a forklift's mast and operator's cab overhead guard employers should follow these guidelines:

- Ensure that forklift operators never position themselves between the forklift operator's cab overhead guard and mast while the forklift is running.

- Ensure that standard operating procedures (SOP) are followed during forklift operation and review these procedures to ensure that they are effective in practice and revise if necessary.

- Ensure that operators do not use alcohol prior to or while operating equipment.

- Consider purchasing or equipping forklifts with an operator safety interlock device such as an Operator Presence Sensing System (OPSS) that prevents movement of the forklift, and its mast and forks when the operator is not seated properly at the controls. 


\section{INTRODUCTION}

In May 2012, the Washington FACE Program was notified by the Washington State Department of Labor and Industries Division of Occupational Safety and Health (DOSH) of the death of a 61-year-old forklift operator and longshore worker who died when he was crushed between a forklift mast and the operator's cab overhead guard.

Washington State FACE investigators reviewed documents which included the victim's death certificate, police report, medical examiner's report, and the DOSH investigation file. WA FACE conducted an incident site investigation and interview with the employer's safety director.

\section{Employer}

The employer operates marine cargo terminals with more than 250 locations worldwide. They have about 500 fulltime employees with a payroll of thousands of casual workers every day, depending on need. Founded in 1949 in Washington State, the employer provides services including:

- Terminal management

- Stevedoring

- Rail yard operations

- Project development management

- Technology system design, installation and training

- Equipment procurement

- Marketing support

- Trucking

- Warehousing

- Off-dock yard operations

\section{Employer Safety Program and Training}

The employer maintains an Injury and Illness Prevention Plan that outlines those work rules covering longshore labor. The plan references the Pacific Coast Marine Safety Code (PCMSC), as well as applicable state and federal requirements for Longshore and Marine Terminal operations. The longshore workers receive General Safety Training (GST) every three years. This training informs the longshore workers of their responsibilities under the PCMSC. Additionally, employees who operate Powered Industrial Trucks (PIT), or forklifts, are required to have training in the operation of that equipment, and they are re-evaluated through a review of their records every three years. The PIT training is through classroom and practical skills demonstration. 
Employees are reminded every shift, through safety talks conducted by longshore foremen of the safety requirements specific to the operation for that shift. As the employer's workforce is considered "casual" labor (from a union hiring hall), they may receive reminders from a foreman and a terminal site safety superintendent of safety requirements when they are found to be in non-compliance. The employer has two fulltime site safety superintendents, one on day shift and one on night shift. There is an employer safety director who reports directly to the company's CEO. Both terminal management and longshore foremen routinely observe terminal operations to ensure that employees are complying with safety rules.

There is a labor/management safety committee. The employer safety director is a member of the committee. There are monthly safety meetings at which the union and management discuss safety issues.

\section{Victim}

The 61-year-old victim was a longshore worker who belonged to the International Longshore and Warehouse Union (ILWU) local affiliate. He was hired as casual labor for the day out of the local union hall. On the day of the fatal incident he was hired to work as a "heavy lift operator." This longshore job title indicated that he was trained and qualified by the union to operate forklifts with load capacities of up to and over 15 tons. He began longshoring in 1982. He been trained through the union and had qualified for and operated numerous types of heavy equipment. He was up-to-date with union and employer required training and had no record of accidents or damage to equipment. $\mathrm{He}$ had worked at this port facility many times.

\section{Equipment}

The piece of equipment involved in the incident was a gas powered forklift manufactured in 2003 by Mitsubishi, model FD 40K (photo 1). The employer purchased the forklift new. It had a load capacity of 8,000 pounds. It was properly maintained and fully functional with all of the required warning stickers, information plates, and operator restraints. The forklift had three hydraulic lift control levers used to adjust the forklift mast and forks. These levers were located behind the dash and to the right of the forklift's steering wheel. The lever closest to the steering wheel moved the forks up or down. The middle lever, when pulled down, tilted the mast

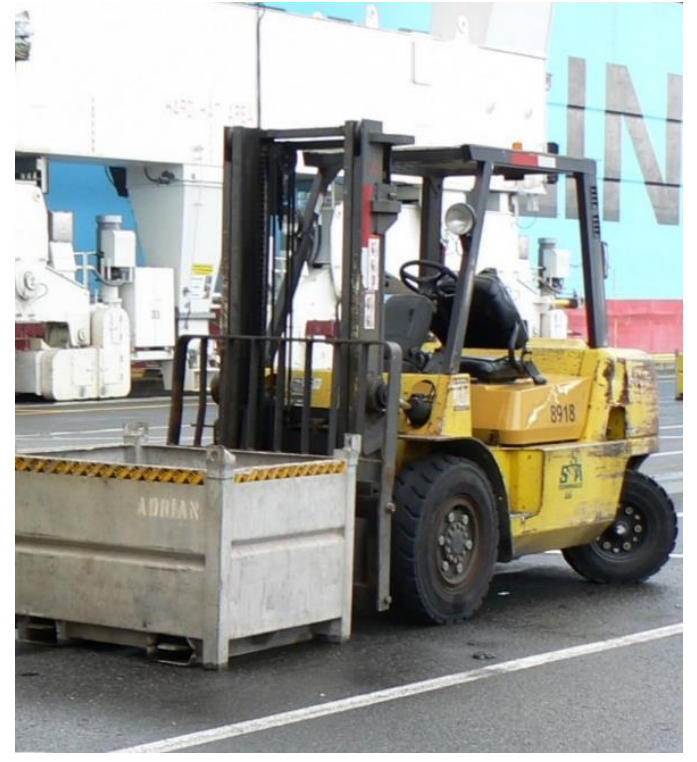

Photo 1: Employer forklift similar to the incident forklift with a cone bin on the incident dock. 
backwards, angling the forks up. The lever farthest from the steering wheel moved the forks side-to-side.

\section{Incident Site}

The incident took place at a marine port terminal dock (photo 2).

\section{Weather}

At the time of the incident, the weather was overcast with a temperature of 61 degrees and a wind speed of 8.1 miles per hour. ${ }^{1}$

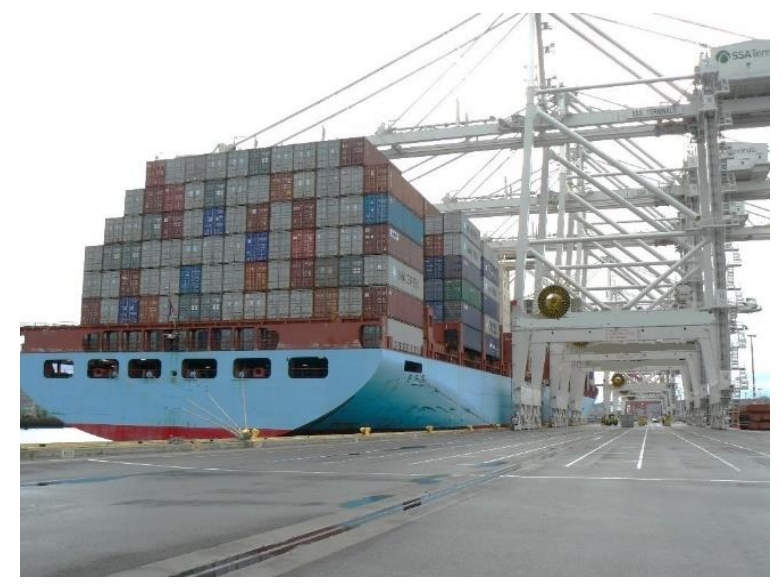

Photo 2: Port terminal dock with ship loaded with shipping containers.

\section{INVESTIGATION}

The victim began his 8-hour night work shift at 6 p.m. at the marine port terminal. The previous evening he had been hired as a casual worker through the International Longshore Workers Union hall (ILWU). His job assignment for that shift was to operate a forklift. This was his usual work at the terminal and he was familiar with the various types of forklift equipment and work procedures. The victim was guaranteed an 8-hour shift. If there was not enough work or he finished his work before the end of the shift, he could go home early and still receive pay for the full eight hours.

That evening, a ship docked at the terminal was to be unloaded of its cargo of shipping containers by container gantry cranes. As cranes discharged the containers from the ship to the dock, workers removed metal devices which secured one container to another to prevent movement at sea. The devices were called "twist locks" or "cones." When removed on the dock, the cones were to be placed in 2' $X 4$ ' $X 4$ ' foot bins provided by the vessel. Individual bins were stowed on the vessel in "flat racks" specifically designed to hold them. These flat racks were discharged to intermodal trailers called chassis and parked on the dock nearby the vessel for the operation (photos 3 and 4).

A forklift operator would then check the contents of the bins on the carts to determine whether they were full or empty and what type of cones they contained, so they could move them to the appropriate locations for further use. In order to see into a bin to check its contents, the established procedure for workers was to drive the forklift beside a trailer and have the operator stand up on

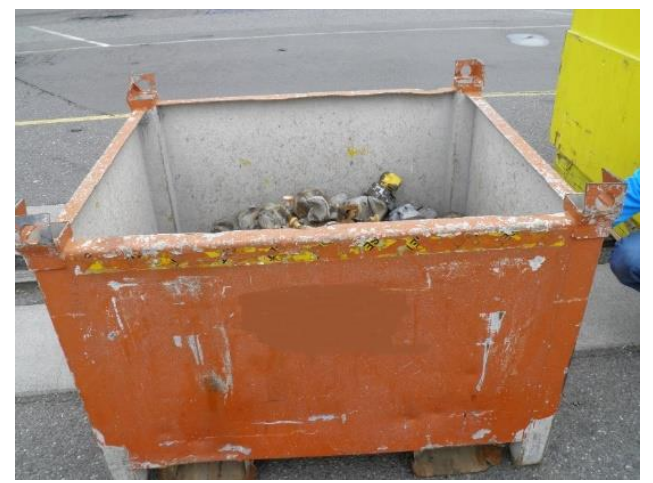

Photo 3: Cone bin. 
the forklift floor and look inside the bins. Alternatively, the operator could lower the bin to ground level.

At the start of his shift the victim checked in with his foreman. The foreman assigned him to move cone bins with a forklift. The forklift he would be operating was an $8,000 \mathrm{lb}$. capacity forklift. He was the only person assigned to that task for that shift. There were about 50 other employees performing various jobs at the terminal. He was working alone on the dock behind a crane, but he was in an area where there was a lot of mobile equipment traffic, and he was not isolated.

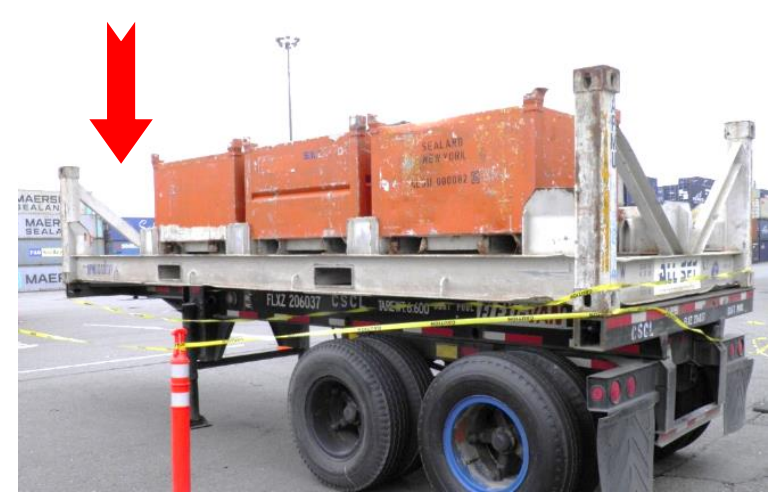

Photo 4: Cone bins set on flat racks loaded on to an intermodal chassis trailer. The arrow indicates the location of the bin that the victim had lifted and elevated on the forks of the forklift.

At 6:24 p.m., while operating the forklift, the victim approached a trailer loaded with four cone bins. He then used the forklift to elevate a cone bin approximately 2 feet above the flat rack mounted on the trailer. The forks were elevated to be about parallel with the top of the forklift's overhead guard. Leaving the forklift's engine running, he then left the operator's seat, climbed over the control console, and stood on the dash of the forklift between the mast and the overhead guard, presumably to look into the elevated bin and perhaps other bins on the trailer. His right foot moved backward and contacted the mast tilt control lever on the console. (The mast tilt lever controls the angle of the forks relative to the ground.) This caused the mast to tilt back, pinning his torso between the mast cross member and the overhead guard (photos 5-9).

Shortly after, the dock foreman saw the victim from a distance and, not realizing what had happened, went over to reprimand him for committing the unsafe act of standing in the bight between the forklift mast and the operator cab overhead guard. He considered this an unusual act, as he had not seen workers do this before. When he arrived at the scene and realized what had happened, the foreman called for help and another forklift operator heard him and came quickly. The foreman pushed the mast tilt lever forward, releasing the victim. Before moving the victim, they noticed that his right foot was in contact with the mast tilt lever located on the operator's console. He and the other operator lifted the conscious victim down from his position on the forklift and placed him on the dock. The responding forklift operator called emergency services. The rescuers spoke with the victim to assess his condition and keep him conscious. The victim complained of pain in his stomach. Another longshoreman arrived and began to administer first aid to the victim. Fire Department paramedics arrived in less than seven 
minutes and began administering aid. He was taken to a hospital, where he died in the emergency room.

Incident investigators made a number of determinations:

- All of the forklift controls functioned properly and required an action by the operator to activate.

- No equipment defect, malfunction, or failure could have contributed to the incident.

- Safety warning labels, including the pinch warning label on top of the mast, were affixed to the forklift and were readable.

- The forklift must be in the "on" position and running for the tilt lever to cause the mast to move.

- The mast tilt control lever is about $1 \frac{1 / 4}{4}$ to $1 \frac{1}{2}$ inches behind the top of the dash.

- Only a half-inch of movement of the mast tilt control lever was necessary to initiate and continue the rearward tilting of the forklift mast.

- A partial reconstruction of the incident showed that the mast was probably tilted backwards approximately 5 degrees from the vertical before the victim's foot contacted the tilt level.

- It took 2 to 3 seconds for the mast to tilt to the full rearward position from a starting backward tilt position of 5 degrees.

- In the full rearward position the mast was approximately 1 inch from the plastic overhead guard cover and 4 inches from metal frame of the overhead guard.

- The mast cross member when in the full rearward position was 42 inches above the forklift dash. The overhead guard was also 42 inches above the dash.

- Fractures on the plastic cover of the overhead guard indicated that the victim was located near or just to the right of the forklift's center line when his torso was crushed between the mast cross member and the overhead guard.

\section{CAUSE OF DEATH}

According to the death certificate, the medical examiner reported the cause of death as "Hemoperitoneum and mechanical asphyxia due to crush injury of torso."

A toxicology report indicated that the victim had a blood alcohol concentration of 0.026 percent. 


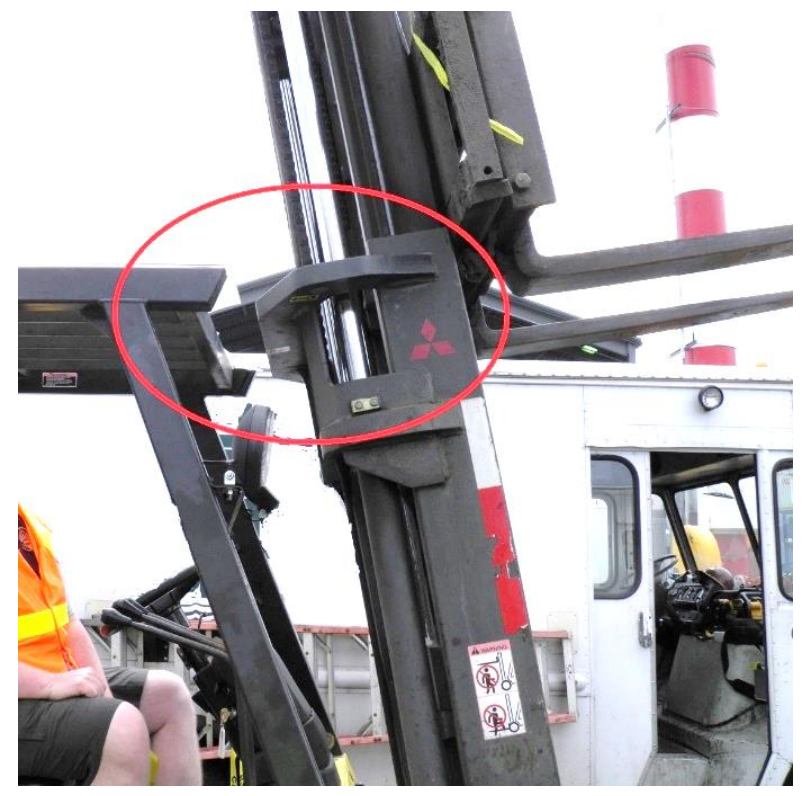

Photo 5: Forklift mast in the full tilted back position. The red circle indicates the area where the victim's torso was crushed between the cross member of the overhead guard and the mast.

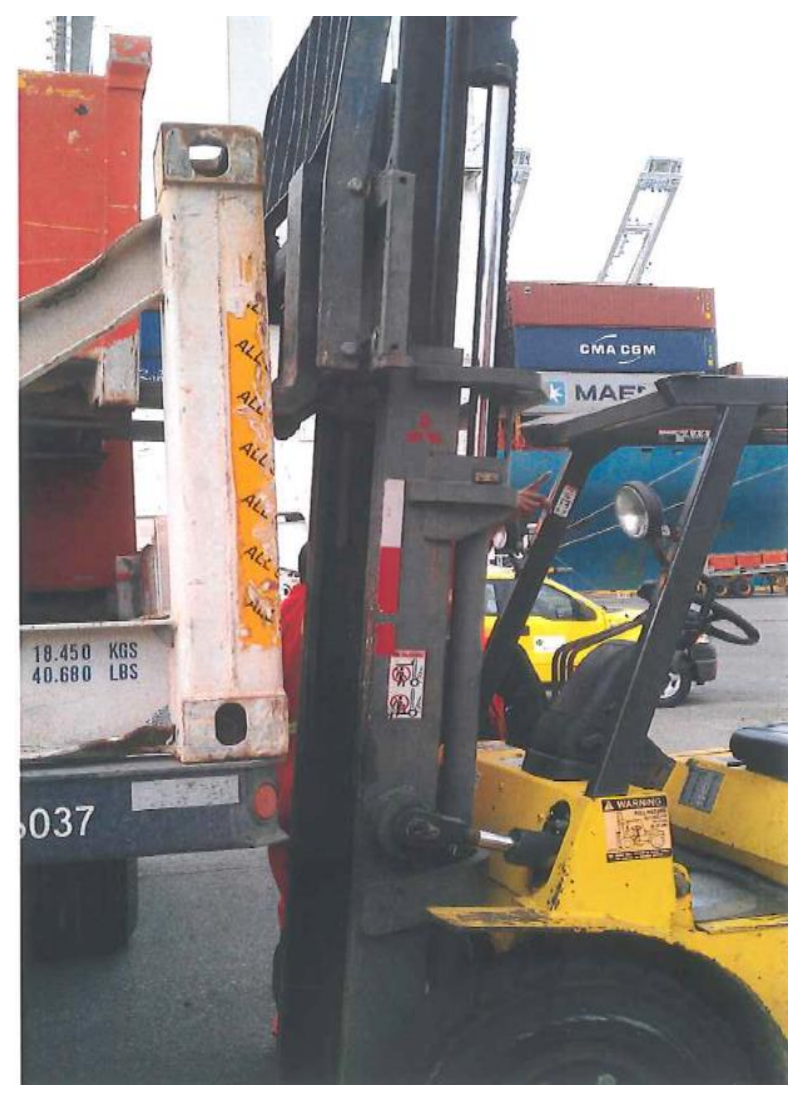

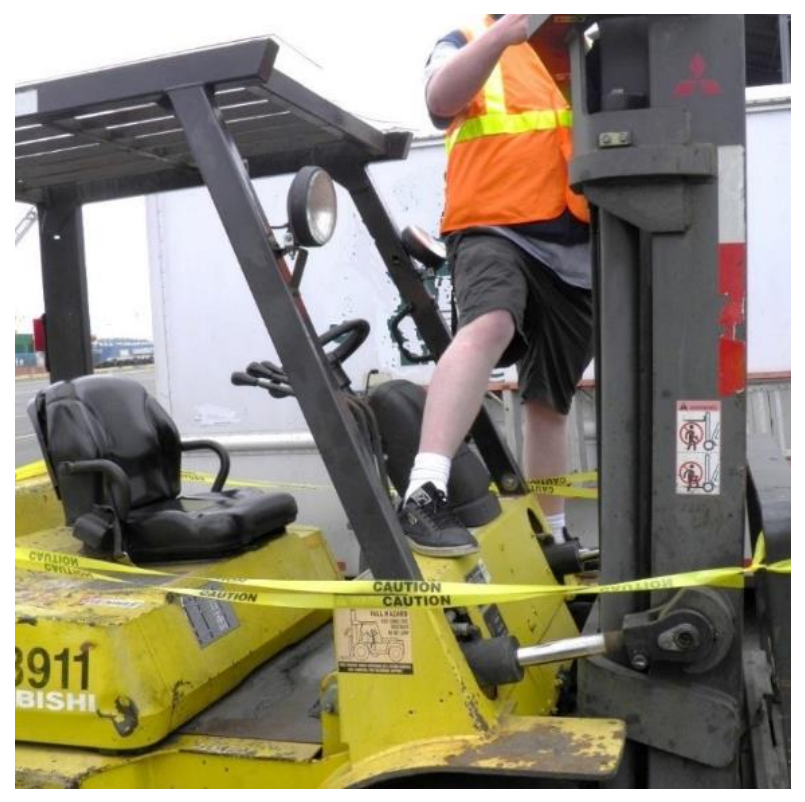

Photo 6: A longshore worker demonstrates how the victim might have accessed the forklift's dash to look into the bin elevated on the forklift's forks. The victim was standing with both feet on the dash when his right foot inadvertently activated the forklift control on the dash that caused the mast to tilt backwards, crushing him against the operator's cab overhead guard.

Photo 7: Recreation of the position of the forklift just before the incident. The forklift is next to the intermodal chassis trailer with a bin elevated on its forks. The victim climbed on to the forklift's dashboard between the mast and overhead guard to look into the bins on the trailer. 


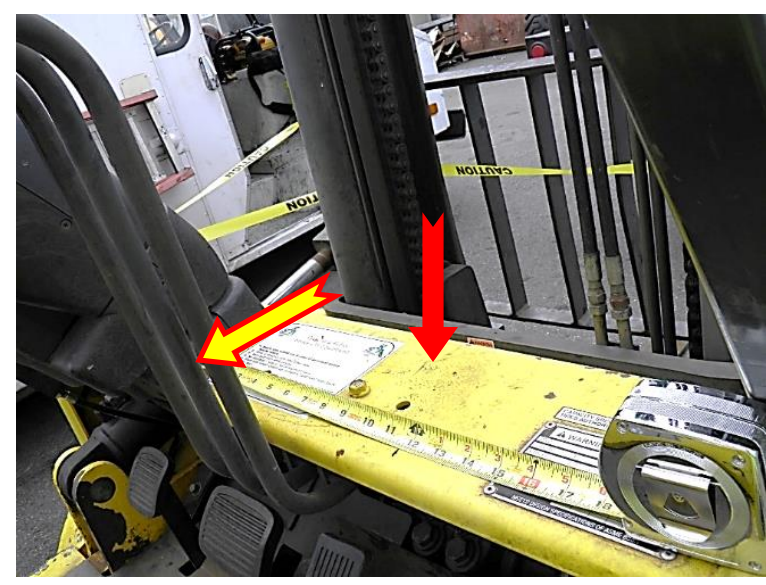

Photo 8: Forklift dash (red arrow) upon which the victim was standing when his foot inadvertently pushed against the mast tilt lever (yellow arrow). View is from inside the operator's cab.

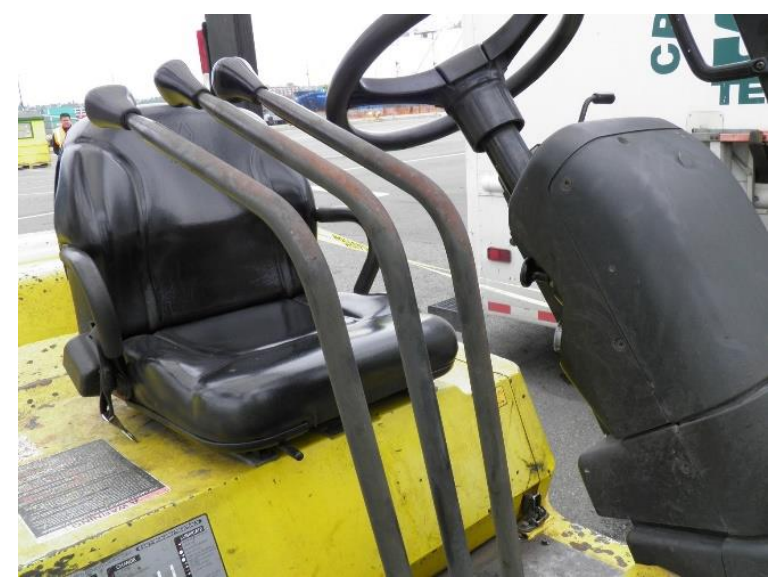

Photo 9: Forklift control levers used to adjust the forks and mast. The middle lever is the mast tilt lever.

\section{CONTRIBUTING FACTORS}

Occupational injuries and fatalities are often the result of one or more contributing factors or key events in a larger sequence of events that ultimately result in the injury or fatality. Washington FACE investigators identified the following factors that may have contributed to the death of the forklift operator:

- Forklift was not operated safely in accordance with the manufacturer's operating manual.

- Forklift was not turned off or otherwise secured when the operator left the operator's seat.

- Forks were not lowered so that the operator could see the contents of the container bin.

- Consumption of alcohol by employee.

POST-INCIDENT CORRECTIVE ACTIONS TAKEN BY EMPLOYER

Following this incident, through an agreement between the longshore workers union and the employer, all bins are now routinely removed from the trailer mounted flat racks and placed on the dock. This

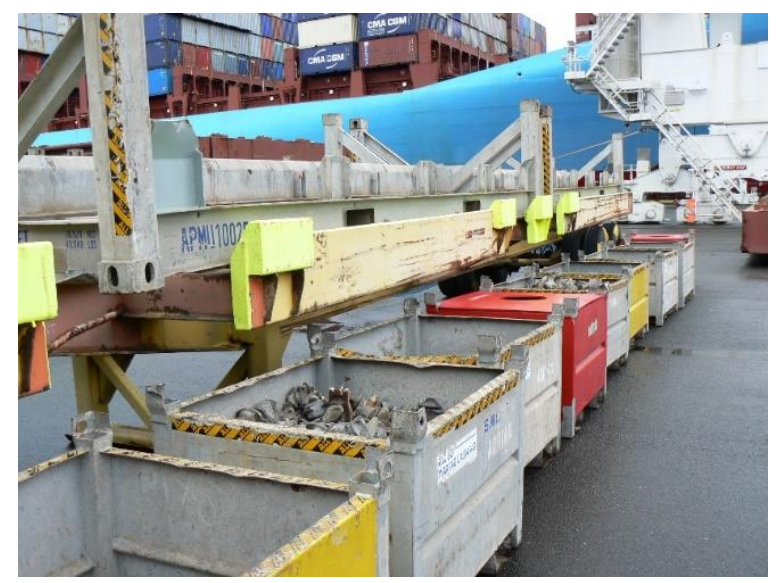

Photo 10: Cone bins on dock after corrective action by the employer was taken. 
allows forklift operators to see into the bins while remaining seated in the forklift (photo 10).

\section{RECOMMENDATIONS AND DISCUSSION}

\section{Recommendation 1: Ensure that forklift operators never position themselves between the forklift operator's cab overhead guard and mast while the forklift is running.}

Discussion: In this incident, the victim was standing on the dash and looking into a bin elevated on the forks of the forklift he was operating. His right foot contacted and engaged the forklift's tilt control lever, causing the lever to move backward, which then tilted the mast backward, crushing him between the cross member of the mast and the overhead guard. To prevent an incident such as this, employers should train forklift operators that before dismounting the forklift the forks should be lowered to the ground, the engine turned off, the parking brake set, and the controls neutralized. In this case, the victim had received forklift training through his union, the ILWU. He had been operating forklifts for over 30 years.

Employers should instruct forklift operators to never put themselves in the area between the forklift's mast and overhead guard of the operator's cab while the forklift is running. Washington State's Division of Occupational Health and Safety (DOSH), Safety Standards for Forklifts and Other Powered Industrial Trucks ${ }^{2}$ require that employers must protect employees who work around powered industrial trucks or forklifts from putting any part of their body between the uprights of the mast and that they must operate them according to the manufacturer's instructions.

The incident forklift's operation and maintenance manual stated:

"Keep all parts of your body away from moving parts such as the mast, carriage, and attachments. Do not put any part of your body between the head guard and he mast. If the mast moves unexpectedly, you could get caught between the mast and the overhead guard and a serious accident could occur."

\section{Recommendation 2: Ensure that standard operating procedures (SOP) are} followed during forklift operation and review these procedures to ensure that they are effective in practice and revise if necessary.

Discussion: At the marine terminal, the SOP for forklift operators was to drive the forklift up beside a trailer and have the operator stand up on the floor of the forklift and look inside the bins. Alternatively, the operator could lower the bin to ground level.

After the fatal incident, a review was undertaken by the employer and the longshore workers union of the current terminal SOP for managing movement and placement of 
cone bins on the dock. Based on this review an agreement was negotiated between the union and the employer requiring that all bins should be routinely removed from the trailer mounted flat racks and placed on the dock. This procedure allows forklift operators to see into the bins while remaining seated in the forklift. This abated the hazards associated with leaving the seat and climbing on the forklift and/or trailer.

\section{Recommendation 3: Ensure that operators do not use alcohol prior to or while operating equipment.}

Discussion: In this incident the victim had a blood alcohol concentration (BAC) of $0.026 \%$. This is a relatively low BAC, and the employer reports the employee did not show signs of "reasonable suspicion" for impairment. However, numerous studies, including a study cited by the National Institute on Alcohol Abuse and Alcoholism, have shown that there is no absolute BAC threshold below which there is no impairment of any kind. Even at BACs as low as 0.01 to 0.02 information processing skills important for operating equipment are impaired. ${ }^{3}$ It is unknown what effect, if any, the victim's consumption of alcohol had on his decision making process that resulted in him placing himself in the hazardous position that resulted in his death.

Employers can address employee alcohol use in the workplace by creating policies, training employees on alcohol abuse awareness, assessing the culture of employee acceptance of alcohol consumption, and referring employees to an employee assistance program or other assistance resources.

Recommendation 4: Consider purchasing or equipping forklifts with an operator safety interlock device such as an Operator Presence Sensing System (OPSS) that prevents powered movement of the forklift, and its mast and forks when the operator is not seated properly at the controls.

Discussion: Various types of safety devices are available that, if installed on the forklift, may have prevented this fatality. Forklift manufacturers have introduced technologies that stop certain hydraulic and transmission functions when the operator leaves the seat or does not fasten the seatbelt. For example, an OPSS detects whether an operator is in the proper operating position. If the operator is not in the proper operating position the forklift will not drive, and the mast will not lift or tilt. 


\section{REFERENCES}

1. Weather Underground.

https://www.wunderground.com/history/airport/KBFl/2012/5/17/DailyHistory.html?re q city $=$ Seattle \&req state $=$ WA\&req statename $=$ Washington\&reqdb. $z i p=98101 \&$ req db. magic $=1 \&$ reqdb. $w$ mo $=99999$

2. Chapter 296-863 WAC. Safety Standards for Forklifts and Other Powered Industrial Trucks.

http://www.Ini.wa.gov/Safety/Rules/Chapter/863/WAC296-

863.pdf\#WAC $296863 \quad 400$

3. National Institute on Alcohol Abuse and Alcoholism. Alcohol Alert. https://pubs.niaaa.nih.gov/publications/aa25.htm

4. Washington State Department of Labor and Industries. Alcohol and Drugs in the Workplace. http://www.Ini.wa.gov/Safety/Topics/AtoZ/AlcoholDrugsWorkplace/

5. NIOSH, Fatality Assessment and Control Evaluation (FACE) Program. Forklift Operator Crushed Between Forklift Cage and Mast while Loading Waste Paper into a Trailer. https://www.cdc.gov/niosh/face/stateface/ma/08ma019.html

6. NIOSH, Fatality Assessment and Control Evaluation (FACE) Program. A Forklift Operator Died When He Was Crushed in the Mast of a Forklift https://www.cdc.gov/niosh/face/stateface/ca/04ca012.html

7. NIOSH, Fatality Assessment and Control Evaluation (FACE) Program. Operator Dies When Caught Between Mast and Cage of Forklift in a Massachusetts Warehouse. https://www.cdc.gov/niosh/face/stateface/ma/98ma049.html

8. NIOSH, Fatality Assessment and Control Evaluation (FACE) Program. Forklift Operator Dies When Head Caught in Lowering Mast. https://www.cdc.gov/niosh/face/stateface/mi/05mi078.html

9. NIOSH, Fatality Assessment and Control Evaluation (FACE) Program. Hispanic Forklift Operator Dies after Being Caught Between Mast and Cage of Forklift - North Carolina. https://www.cdc.gov/niosh/face/ln-house/full200209.html

10. NIOSH, Fatality Assessment and Control Evaluation (FACE) Program. A Yard Hand Was Killed When He Was Crushed Between the Mast and the Rollover Protective Structure of a Forklift. https://www.cdc.gov/niosh/face/stateface/ok/04ok028.html 


\section{INVESTIGATOR INFORMATION}

Todd Schoonover has a PhD in Industrial Hygiene from the University of Illinois at Chicago. He is a Certified Industrial Hygienist $(\mathrm{ClH})$ and Certified Safety Professional (CSP). Todd is currently the Principle Investigator for the WA FACE Program.

Christina Rappin has a BAS from The Evergreen State College. She is a Research Investigator with the WA FACE program.

Randy Clark has a BA from the Evergreen State College. He is a Safety and Health Specialist with the WA FACE Program.

Washington State FACE Program Information

The Washington State Fatality Assessment and Control (WA FACE) program is one of many workplace health and safety programs administered by the Washington State Department of Labor \& Industries' Safety \& Health \& Research for Prevention (SHARP) program. It is a research program designed to identify and study fatal occupational injuries. Under a cooperative agreement with the National Institute for Occupational Safety and Health (NIOSH grant\# 5 U60 OH008487), WA FACE collects information on occupational fatalities in WA State and targets specific types of fatalities for evaluation. WA FACE investigators evaluate information from multiple sources. Findings are summarized in narrative reports that include recommendations for preventing similar events in the future. These recommendations are distributed to employers, workers, and other organizations interested in promoting workplace safety. NIOSH-funded, statebased FACE programs include: California, Kentucky, Massachusetts, Michigan, New York, Oregon, and Washington. WA FACE does not determine fault or legal liability associated with a fatal incident. Names of employers, victims and/or witnesses are not included in written investigative reports or other databases to protect the confidentiality of those who voluntarily participate in the program.

Additional information regarding the WA FACE program can be obtained from:

www.Ini.wa.gov/Safety/Research/FACE/default.asp

\section{ACKNOWLEDGMENTS}

This report was reviewed by stakeholders from labor and business communities and various Washington State and Federal worker safety agencies. Though we are unable to acknowledge specific individuals for their contributions to this report, we would like to recognize the following for their help and support of the FACE mission and objectives:

- The employer involved in the incident

- Division of Occupational Safety and Health (DOSH)

- Federal FACE Program management (NIOSH)

- Safety \& Health Assessment \& Research for Prevention (SHARP) 